\title{
Molecular Phylogenetics of the genus Hexachlamys (Myrtaceae) using chloroplast and nuclear markers
}

\author{
Fernanda Cruz ${ }^{1 *}$, Andreia Turchetto-Zolet ${ }^{1}$, Nicole Veto ${ }^{2}$, Cláudio Mondin $^{3}$, Maurício Almerão ${ }^{2}$, Rogério Margis ${ }^{4}$ \\ From IUFRO Tree Biotechnology Conference 2011: From Genomes to Integration and Delivery \\ Arraial d'Ajuda, Bahia, Brazil. 26 June - 2 July 2011
}

\section{Background}

Myrtaceae family includes more than 3,800 species of trees and shrubs, distributed mainly in tropical and subtropical regions of the world. Representatives of this family have great ecological significance for forest ecosystems, and are economically important species in the pharmaceutical, food, cosmetic and perfumery industry [1]. The genus Hexachlamys Berg. (Myrtaceae) has about 10 species distributed from the Southern to the Southeast of Brazil, and it also occurs in Paraguay, Argentina, Bolivia and Uruguay [2,3]. Since 1968 it has been considered an independent genus. It is distinguished morphologically from the genus Eugenia by pentamerous or hexamerous flowers and exserta radicle, and as many genera and species of the Myrtaceae family, it has a complex taxonomic classification $[2,4,5]$. The goal of this study was to conduct a molecular phylogenetic analysis among species of the genus Hexachlamys (Myrtaceae) using chloroplast (cpDNA) and nuclear (nrDNA) markers, and to verify its phylogenetic relationships with the genus Eugenia in order to contribute to the systematics and taxonomy of it.

\section{Methods}

The samples were collected as leaf material(from herbaria species and samples collected in the field) of the genus Hexachlamys representing all described species, as indicated in herbariums and species of the Eugenia genus that occur in the Rio Grande do Sul state. Total genomic DNA was extracted using the CTAB method based on the protocol already described [6] and used for

\footnotetext{
* Correspondence: fernandacruz86@hotmail.com

'Programa de Pós-Graduação em Genética e Biologia Molecular,

Universidade Federal do Rio Grande do Sul (UFRGS), Brazil

Full list of author information is available at the end of the article
}

the PCR reactions. PCR products were sequenced on ABI PRISM 3100 sequencer (Applied Biosystem). Nucleotide sequences were aligned using CLUSTALW [7] implemented in MEGA5 (Molecular Evolutionary Genetics Analysis) version 5.0 [8], then checked visually and carefully improved manually before analysis. The phylogenetic analysis was reconstructed after nucleotide sequence alignments using three different approaches: the neighbor-joining $(\mathrm{NJ})$, the Bayesian and the Maximum-Likelihood (ML) methods. The NJ, Bayesian and ML analysis were performed in MEGA 5.0, MrBayes [9] and PhyML [10], respectively.

\section{Results and conclusions}

To date we obtained DNA sequences of 21 species of the genus Eugenia and seven species of the genus Hexachlamys. Universal primers that amplify chloroplast region (trnL-trnF, trnL-intron, ycf5, accD, rbcLa, psbAtrnH, rpoB, rpoC1, ndhJ, matK and rps16) and nuclear (ITS) were tested. The regions used for the phylogenetic analisys were chloroplast $a c c D$, rpoB, rpoClgenes and the nuclear ITS, since the other chloroplast regions were not possible to amplify and sequence in all sampled species. These cpDNA and nrDNA regions presented polymorphisms among species studied. Results from Bayesian, NJ and ML tree analysis produced similar topologies and revealed that Hexachlamys species did not form a monophyletic clade. The Hexachlamys species have grouped together Eugenia species with high bootstrap values, indicating that Hexachlamys can be a synonymous of genus Eugenia. These results corroborate with morphological data [11]. To confirm these results, other cpDNA and nrDNA markers will be tested and Hexachlamys species will be collected to substitute the species obtained in herbarium, since we found 
difficulties in the amplification of these species with all markers previously tested. This study can contribute to taxonomic classification of this group, as well as the field of conservation, since these species have an important economically and ecologically role.

Financial support: CNPq and FAPERGS

\section{Author details}

'Programa de Pós-Graduação em Genética e Biologia Molecular, Universidade Federal do Rio Grande do Sul (UFRGS), Brazil. ${ }^{2}$ Centro de Biotecnologia UFRGS, Brazil. ${ }^{3}$ Pontifícia Universidade Católica do Rio Grande do Sul, PUCRS, Brazil. ${ }^{4}$ Centro de Biotecnologia UFRGS, Pesquisador CNPq, Brazil.

Published: 13 September 2011

\section{References}

1. Barroso GM, Peron MV: Myrtaceae Aspectos florísticos das espécies vasculares.J. Botânico 1994, 261-302.

2. Mcvaugh $R$ : The genera of american myrtaceae, a interim report. Taxon 1968, 17:354-418.

3. Legram CD, Klein RM: Mirtáceas. Flora ilustrada catarinense 1969, 172

4. Mcvaugh R: Tropical american myrtaceae. Chicago Natural History Museum 1956, 29.

5. Schmid R: Resolution of eugenia-syzygium controversy (myrtaceae). Am J Bot 1972, 59:423.

6. Doyle JJ, Doyle JL: Isolation of plant DNA from fresh tissue. Focus 1987, 12:13-15.

7. Thompson JD: Clustal-W - improving the sensitivity of progressive multiple sequence alignment through sequence weighting, positionspecific gap penalties and weight matrix choice. Nucleic Acids Res 1994, 22(22):4673-4680.

8. Tamura K, Dudley J, Nei M, Kumar S: Mega4: Molecular evolutionary genetics analysis (mega) software version 4.0. Mol Biol Evol 2007, 24:1596-9.

9. Ronquist F, Huelsenbeck JP: Mrbayes 3: Bayesian phylogenetic inference under mixed models. Bioinformatics 2003, 19(12):1572-1574.

10. Guindon S, J F: Estimating maximum likelihood phylogenies with PhyML. Mol Biol 2009, 9(3):384-385.

11. Sobral M: A Família das Myrtaceae no Rio Grande do Sul. Edição Unisinos; 2003, 216.

doi:10.1186/1753-6561-5-S7-P6

Cite this article as: Cruz et al: Molecular Phylogenetics of the genus Hexachlamys (Myrtaceae) using chloroplast and nuclear markers. BMC Proceedings 2011 5(Suppl 7):P6.

\section{Submit your next manuscript to BioMed Central and take full advantage of:}

- Convenient online submission

- Thorough peer review

- No space constraints or color figure charges

- Immediate publication on acceptance

- Inclusion in PubMed, CAS, Scopus and Google Scholar

- Research which is freely available for redistribution

Submit your manuscript at www.biomedcentral.com/submit
C Biomed Central 